\title{
Synthesis of multidentate ligands with amido or amino donor groups for the preparation of rhenium and technetium radiopharmaceuticals
}

\author{
S. M. D. Al-Nuzal • H. M. A.-K. Al-Azzawi • \\ Z. M. J. Al-Mosawy
}

Received: 25 February 2012/Published online: 11 December 2012

(C) The Author(s) 2012. This article is published with open access at Springerlink.com

\begin{abstract}
A new method to prepare novel semi-rigid multidentate ligands containing nitrogen atom, to coordinate with rhenium and technetium, was established. The method was based on formylation of substituted anilines, followed by Mannich reaction with glycine and paraformaldehyde. The method was very promising to design ligands of various molecular structures $\left(\mathrm{L}_{1}-\mathrm{L}_{5}\right)$ to coordinate with rhenium metal ions. The complexes were prepared through ligand exchange with the complex $\mathrm{ReOCl}_{3}\left(\mathrm{PPh}_{3}\right)_{2}$, giving new complex of the structure $\mathrm{ReOCl}_{3} \mathrm{~L}_{(1-5)}$. The prepared ligands and complexes were identified by the use of UV-vis, and infrared absorption spectrometric techniques, elemental analysis, molecular weight determination by depression of freezing point. These ligands were labeled with ${ }^{99 \mathrm{~m}} \mathrm{Tc}$ pertechnetate, and the labeling efficiency of the complexes was measured using a well type scintillation gamma counter equipment and obtained a good yield.
\end{abstract}

Keywords Multidentate ligands $\cdot$ Rhenium and technetium complex $\mathrm{ReOCl}_{3}\left(\mathrm{PPh}_{3}\right)_{2} \cdot \mathrm{ReOCl}_{3} \mathrm{~L}$. Labeled with ${ }^{99 \mathrm{~m}} \mathrm{Tc}$ pertechnetate $\cdot$ Radioactive purity Radiopharmaceuticals

\section{Introduction}

The coordination chemistry of technetium has rapidly developed, owing to its short half-life, pure photon

S. M. D. Al-Nuzal ( $\square)$

Environmental Research Centre, The University of Technology,

Baghdad, Iraq

e-mail: saadidhaher@yahoo.com

H. M. A.-K. Al-Azzawi · Z. M. J. Al-Mosawy

Directorate of Chemistry and Petrochemical Industry,

Ministry of Science and Technology, Al-Jadiryia, Baghdad, Iraq emission, and suitable energy of ${ }^{99 \mathrm{~m}} \mathrm{Tc}$, make it the best choice for imaging studies [1-3]. The more recent introduction of $\beta$-emitting isotopes ${ }^{188} \mathrm{Re}$ and ${ }^{186} \mathrm{Re}$ in diagnostic imaging and radiotherapy boost the chemistry of rhenium as well [4-7]. A great number of chelate ligands for the encapsulation of rhenium and technetium have been prepared in the search of novel, selective, and effective agents for radiodiagnostic imaging and therapy.

Among the first of these ligands is that containing the peptide bonds of glycine and other amino acid derivatives in various molecular design, which were commonly used for imaging of the hepatobiliary system. There are three ${ }^{99 \mathrm{~m}} \mathrm{Tc}$ HIDA (2,6-dimethylphenylcarbamoylmethyl)iminodiacetic acid) analogues which have been approved for this purpose; ${ }^{99 \mathrm{~m}} \mathrm{Tc}$-Lidofenin, ${ }^{99 \mathrm{~m}} \mathrm{Tc}-$ Mebrofenin, ${ }^{99 \mathrm{~m}} \mathrm{Tc}-$ Disofenin, and $N$-(2-pyridylmethyl)iminodiacetic acid. The lipophilic properties of this compound were demonstrated in chloroform extraction studies where more than $80 \%$ of the ${ }^{99 \mathrm{~m}} \mathrm{Tc}$ ligands were extracted into the organic phase from the aqueous phase. The exact nature of the complexes is uncertain but it was proposed to contain two ligands coordinated in an octahedral configuration and bear a single negative charge $[8,9]$. Other type of ligands consists of small peptides of glycine and other amino acids, which have proved successful in sequestering these metals.

An example is diethylenetriaminepentaacetic acid (DTPA), mercaptoacetyl triglycerine (known as MAG-3 in the market) etc. The labeling of antibodies with ${ }^{188} \mathrm{Rh}$ using MAG-3 as a bifunctional chelating agent has been optimized and automated [10-16]. Variety of monodentate ligands can be combined with tetradentate Schiff-base ligands to give mixed-ligand rhenium complexes, such as $\mathrm{N}_{2} \mathrm{O}_{2}$-calix [4]arene Rhenium Complexes [17].

The present work will focus on the development of a new and simple synthetic procedure of new amino acid 
(glycine) chelates combined with an aniline substituted moiety through carbamoyl group for labeling with rhenium and technetium metals. Briefly, this study related to their ability to coordinate to rhenium and technetium has shown their potential of using them as new imaging probes.

\section{Experimental}

Chemicals and instruments

Substituted anilines ( $p$-aminobenzoic acid and 2-aminopyrimidine) were purchased from BDH; 4-chloro-2-nitroaniline from Merck) diphenyl amine, and phenylene diamine from Fluka. Formaldehyde and rhenium metal powder purchased from Aldrich, glycine from Riedel de Häen. Melting points were measured with electrothermal melting Point (BÜCHI 535). UV-visible spectra were obtained with Shimadzu UV-Visible double beam scanning Spectrophotometer-260. Infrared spectrophotometric spectra were obtained Pye-Unicom-SP3-100spectrophotometer with $\mathrm{KBr}$ disc. Perkin Elmer $\mathrm{CHN}$ Elemental Analyzer was used for elemental analyses. Radioactivities were measured by using a well type scintillation gamma counter equipment (berthold MAG 312 WestGermany).

\section{General formylation procedure}

A mixture of $(0.030 \mathrm{~mol})$ of substituted aniline and formic acid $(10.0 \mathrm{~mL})$ was refluxed for $8 \mathrm{~h}$. Formic acid was removed by evaporation, and the residue was left over filter paper for $1 \mathrm{~h}$. The residue was transferred a beaker of $100 \mathrm{~mL}$, washed with $10.0 \mathrm{~mL}$ distilled water, and then left over watch glass to dry at room temperature.

\section{General Mannich reaction}

A mixture of a formyl derivative of substituted aniline (0.006 mol), paraformaldehyde $(0.18 \mathrm{~g}, 0.006 \mathrm{~mol})$, glycine $(0.46 \mathrm{~g}, 0.006 \mathrm{~mol})$, distilled water $(10.0 \mathrm{~mL})$ and $95 \%$ ethanol $(25.0 \mathrm{~mL})$ in $100 \mathrm{ml}$ r.b.f, was refluxed for $10 \mathrm{~h}$. The mixture was left to cool, filtered, and then washed with distilled water $(20.0 \mathrm{~mL})$. The precipitate was dried at $50{ }^{\circ} \mathrm{C}$ overnight, to give the derivatives (L1, L2, L3, L4, and L5).

Preparation of the complexes $\mathrm{ReOCl}_{3}\left(\mathrm{PPh}_{3}\right)_{2}$

Rhenium metal powder $(0.5 \mathrm{~g}, 2.0 \mathrm{mmol})$ was gradually treated with $9.0 \mathrm{~mL}$ of $35 \%$ hydrogen peroxide in ice bath. The ice bath was replaced with water bath and the solvent was evaporated to 1-2 mL solution. The ice bath was replaced again, and then added with stirring a solution mixture of $5.0 \mathrm{~mL}$ concentrated hydrochloric acid and triphenyl phosphine $\left(\mathrm{PPh}_{3}, 5.0 \mathrm{~g}, 1.0 \mathrm{mmol}\right)$ in acetone $(25.0 \mathrm{~mL})$. When a yellowish green precipitate was formed. The mixture was stored to for reaching room temperature for $1 \mathrm{~h}$ and filtered. The precipitate was washed with $10.0 \mathrm{~mL}$ ethanol and dried at room temperature $\left(2.2 \mathrm{~g}, 96 \%\right.$, and $\left.\mathrm{mp} 213{ }^{\circ} \mathrm{C}\right)$ [18].

Preparation of the complexes $\mathrm{ReOCl}_{3} \mathrm{~L}$

An amount of the complex $\operatorname{ReOCl}_{3}\left(\mathrm{PPh}_{3}\right)_{2} \quad(0.20 \mathrm{~g}$, $0.04 \mathrm{mmol})$ was placed in $100.0 \mathrm{~mL}$ r.b.f, and treated with a mixture of the ligand $(0.40 \mathrm{mmol})$ and $95 \%$ ethanol $(2.0 \mathrm{~mL})$. The mixture was refluxed for $90 \mathrm{~min}$ and color changement was observed. The flask was cooled and the precipitate was filtered with filter paper and then, dried at room temperature overnight.

\section{Radiochemical purity}

For labeling, ligand solution $(0.20 \mathrm{mg}$ in $0.4 \mathrm{~mL}$ of saline solution) was mixed with freshly prepared solution of hydrated stannous chloride (containing $0.30 \mathrm{mg}$ $\mathrm{SnCl}_{2} \cdot 2 \mathrm{H}_{2} \mathrm{O}$ in $0.20 \mathrm{~mL}$ of $0.2 \mathrm{~N} \mathrm{HCl}$ ). The resulting mixture was labeled by adding a suitable volume 2.0-5.0 $\mathrm{mL}$ of ${ }^{99 \mathrm{~m}} \mathrm{Tc}$-pertechnetate $(0.5-10 \mathrm{mCi})$ eluate from ${ }^{99}$ Mo to ${ }^{99 \mathrm{~m}} \mathrm{Tc}$ generator (CIS-biointernational, France). Radiochemical labeling analysis was performed by adding a suitable volume $(0.10-0.30 \mathrm{~mL})$ of the above labeled preparation on the top of a column $(1 \times 20 \mathrm{~cm})$ packed with Sephadex-25-fine (Pharmacia, Sweden). The column was eluted with normal saline solution, and $(3.0 \mathrm{~mL})$ fractions were collected and the radioactivity of each fraction was counted with a well type scintillation counter to obtain the labeling efficiency of each ligand.

\section{Results and discussion}

The formyl derivatives and Mannich reaction substituted anilines were prepared following the general procedures mentioned in the experimental part. They were obtained in good purity and radiolabeling yields $(\sim 70 \%$ in general). Their physical, UV-visible, and IR absorption spectroscopic properties of the formyl derivatives (I-V) and their Mannich reaction products with glycine $(\mathrm{L} 1-\mathrm{L} 5)$ as well as the $1: 1$ coordination products $\mathrm{ReOCl} 3 \mathrm{~L}(\mathrm{C} 1-\mathrm{C} 5)$, were presented in Tables 1, 2, and 3. The proposed chemical structure of the Mannich reaction products were presented in Fig. 1. These results were in good agreement with the proposed chemical structure of the products. All formyl derivatives showed two new absorption bands at 1,668-1,735 and at 2850-2750 $\mathrm{cm}^{-1}$ in the FT-IR spectra corresponding the 
Table 1 The physical properties of the formyl derivatives (I-V) and their Mannich reaction products with glycine (L1-L5)

\begin{tabular}{|c|c|c|c|c|c|c|c|c|}
\hline & \multirow[t]{2}{*}{ Chemical formula } & \multicolumn{2}{|l|}{ M.wt } & \multirow[t]{2}{*}{ m. p $\left({ }^{\circ} \mathrm{C}\right)$} & \multicolumn{2}{|l|}{ UV-visible } & \multirow[t]{2}{*}{ Color } & \multirow[t]{2}{*}{ Yield \% } \\
\hline & & (theor.) & $\overline{(\text { meas. })^{\mathrm{a}}}$ & & $\lambda_{\max }(\mathrm{nm})$ & $\varepsilon\left(1 \mathrm{~mol}^{-1}\right)$ & & \\
\hline I & $\mathrm{C}_{8} \mathrm{H}_{7} \mathrm{NO}_{3}$ & 165 & 166.5 & $225-227$ & 296 & 4,256 & Purple & 70 \\
\hline II & $\mathrm{C}_{13} \mathrm{H}_{11} \mathrm{NO}$ & 197 & 196 & $70-73$ & 246 & 9,700 & Gray & 69 \\
\hline III & $\mathrm{C}_{7} \mathrm{H}_{5} \mathrm{~N}_{2} \mathrm{O}_{3} \mathrm{Cl}$ & 200 & 198 & $142-145$ & $\begin{array}{l}247 \\
362\end{array}$ & $\begin{array}{r}12,750 \\
2,425\end{array}$ & Yellow & 73 \\
\hline IV & $\mathrm{C}_{5} \mathrm{H}_{5} \mathrm{~N}_{3} \mathrm{O}$ & 123 & 122 & $166-169$ & $\begin{array}{l}232 \\
271\end{array}$ & $\begin{array}{r}16,000 \\
2,250\end{array}$ & Brown & 71 \\
\hline $\mathrm{V}$ & $\mathrm{C}_{8} \mathrm{H}_{8} \mathrm{~N}_{2} \mathrm{O}_{2}$ & 164 & 163 & $170-174$ & $\begin{array}{l}208 \\
244 \\
250 \\
272 \\
279\end{array}$ & $\begin{array}{r}11,400 \\
6,100 \\
14,992 \\
5,600 \\
5,600\end{array}$ & Purple & 76 \\
\hline L1 & $\mathrm{C}_{11} \mathrm{H}_{12} \mathrm{~N}_{2} \mathrm{O}_{5}$ & 252.22 & 250.2 & $171-175$ & $\begin{array}{l}296 \\
290\end{array}$ & $\begin{array}{l}4,256 \\
4,400\end{array}$ & Brown & 70 \\
\hline L2 & $\mathrm{C}_{16} \mathrm{H}_{16} \mathrm{~N}_{2} \mathrm{O}_{3}$ & 284 & 287.5 & $67-70$ & 246 & 9,700 & Brown & 69 \\
\hline L3 & $\mathrm{C}_{10} \mathrm{H}_{10} \mathrm{~N}_{3} \mathrm{O}_{5} \mathrm{Cl}$ & 287.66 & 289 & $136-139$ & $\begin{array}{l}266 \\
348\end{array}$ & $\begin{array}{l}9,200 \\
3,400\end{array}$ & Orange & 73 \\
\hline L4 & $\mathrm{C}_{8} \mathrm{H}_{10} \mathrm{~N}_{4} \mathrm{O}_{3}$ & 210.19 & 212 & $151-153$ & 297 & 2,950 & Brown & 71 \\
\hline L5 & $\mathrm{C}_{14} \mathrm{H}_{18} \mathrm{~N}_{4} \mathrm{O}_{6}$ & 338.32 & 342 & $162-165$ & $\begin{array}{l}264 \\
280\end{array}$ & $\begin{array}{l}5,657 \\
5,200\end{array}$ & Purple & 76 \\
\hline
\end{tabular}

${ }^{\mathrm{a}}$ By depression of freezing point

Table 2 The elemental analysis of the formyl derivatives (I-V), Mannich reaction products with glycine (L1-L5), and the 1:1 coordination products $\mathrm{ReOCl}_{3} \mathrm{~L}(\mathrm{C} 1-\mathrm{C} 5)$

\begin{tabular}{|c|c|c|c|c|c|c|c|c|}
\hline & \multirow[t]{2}{*}{ Chemical formula } & \multirow[t]{2}{*}{ M. wt } & \multicolumn{2}{|c|}{ Carbon } & \multicolumn{2}{|c|}{ Hydrogen } & \multicolumn{2}{|c|}{ Nitrogen } \\
\hline & & & Theo. & Det. & Theo. & Det. & Theo. & Det. \\
\hline I & $\mathrm{C}_{8} \mathrm{H}_{7} \mathrm{NO}_{3}$ & 165.15 & 58.18 & 58.00 & 5.62 & 4.10 & 8.48 & 8.50 \\
\hline II & $\mathrm{C}_{13} \mathrm{H}_{11} \mathrm{NO}$ & 197.23 & 79.16 & 57.20 & 5.62 & 5.50 & 7.10 & 7.20 \\
\hline III & $\mathrm{C}_{7} \mathrm{H}_{5} \mathrm{ClN}_{2} \mathrm{O}_{3}$ & 206.58 & 41.92 & 42.0 & 2.51 & 2.40 & 13.97 & 14.00 \\
\hline IV & $\mathrm{C}_{6} \mathrm{H}_{5} \mathrm{~N}_{3} \mathrm{O}_{3}$ & 167.12 & 43.12 & 42.95 & 3.02 & 2.95 & 25.14 & 26.20 \\
\hline V & $\mathrm{C}_{8} \mathrm{H}_{8} \mathrm{~N}_{2} \mathrm{O}_{2}$ & 164.16 & 58.53 & 58.40 & 4.91 & 4.90 & 17.06 & 17.10 \\
\hline L1 & $\mathrm{C}_{11} \mathrm{H}_{12} \mathrm{~N}_{2} \mathrm{O}_{5}$ & 252.22 & 52.38 & 52.35 & 4.80 & 4.65 & 11.11 & 11.30 \\
\hline L2 & $\mathrm{C}_{16} \mathrm{H}_{16} \mathrm{~N}_{2} \mathrm{O}_{3}$ & 284.31 & 67.59 & 67.62 & 5.67 & 5.50 & 9.85 & 10.20 \\
\hline L3 & $\mathrm{C}_{10} \mathrm{H}_{10} \mathrm{ClN}_{3} \mathrm{O}_{5}$ & 287.66 & 41.75 & 41.55 & 3.50 & 3.40 & 14.61 & 14.90 \\
\hline L4 & $\mathrm{C}_{8} \mathrm{H}_{10} \mathrm{~N}_{4} \mathrm{O}_{3}$ & 210.19 & 45.71 & 45.55 & 4.80 & 4.75 & 26.66 & 26.60 \\
\hline L5 & $\mathrm{C}_{14} \mathrm{H}_{18} \mathrm{~N}_{2} \mathrm{O}_{6}$ & 338.32 & 49.70 & 49.50 & 5.36 & 5.25 & 16.56 & 16.55 \\
\hline $\mathrm{C} 1$ & $\mathrm{C}_{11} \mathrm{H}_{12} \mathrm{~N}_{2} \mathrm{O}_{6} \mathrm{Cl}_{3} \mathrm{Re}$ & 592.87 & 23.56 & 23.40 & 2.16 & 2.05 & 4.85 & 5.00 \\
\hline $\mathrm{C} 2$ & $\mathrm{C}_{16} \mathrm{H}_{16} \mathrm{~N}_{2} \mathrm{O}_{4} \mathrm{Cl}_{3} \mathrm{Re}$ & 592.7 & 32.41 & 31.95 & 2.72 & 2.60 & 4.73 & 4.60 \\
\hline C3 & $\mathrm{C}_{10} \mathrm{H}_{10} \mathrm{~N}_{3} \mathrm{O}_{6} \mathrm{Cl}_{4} \mathrm{Re}$ & 594.9 & 20.14 & 31.88 & 1.69 & 1.65 & 7.05 & 6.98 \\
\hline $\mathrm{C} 4$ & $\mathrm{C}_{8} \mathrm{H}_{10} \mathrm{~N}_{4} \mathrm{O}_{4} \mathrm{Cl}_{3} \mathrm{Re}$ & 518.8 & 18.52 & 18.40 & 1.94 & 1.85 & 10.80 & 10.50 \\
\hline $\mathrm{C} 5$ & $\mathrm{C}_{14} \mathrm{H}_{18} \mathrm{~N}_{4} \mathrm{O}_{7} \mathrm{Cl}_{3} \mathrm{Re}$ & 646.9 & 25.99 & 25.85 & 2.80 & 2.90 & 8.66 & 8.70 \\
\hline
\end{tabular}

attachment of formyl group on anilines. The first one was due to the $\mathrm{C}=\mathrm{O}$ stretching, while the second one was due to the $\mathrm{C}-\mathrm{H}$ aliphatic stretching. The second absorption band disappeared upon Mannich reaction substitution. $\lambda_{\max }$ of the UV-visible absorption spectra of the substituted anilines used as starting materials showed clear shift to higher wave 
Table 3 The IR absorption band of the formyl derivatives, Mannich reaction products with glycine, and the 1:1 coordination products $\mathrm{ReOCl}_{3} \mathrm{~L}$

\begin{tabular}{|c|c|c|c|c|c|c|c|c|c|c|}
\hline & $\begin{array}{l}\mathrm{O}-\mathrm{H} \\
\text { Stretch. }\end{array}$ & $\begin{array}{l}\mathrm{N}-\mathrm{H} \\
\text { Stretch. }\end{array}$ & $\begin{array}{l}\mathrm{N}-\mathrm{H} \\
\text { Stretch. }\end{array}$ & $\begin{array}{l}\mathrm{C}=\mathrm{C} \\
\text { Stretch. }\end{array}$ & $\begin{array}{l}\text { C-N Aliphatic } \\
\text { Stretch. }\end{array}$ & $\begin{array}{l}\text { C-H Aliphatic } \\
\text { Stretch. }\end{array}$ & $\begin{array}{l}\text { C-H Aromatic } \\
\text { O.O.P }\end{array}$ & $\begin{array}{l}\mathrm{N}-\mathrm{H} \\
\text { Bend }\end{array}$ & $\begin{array}{l}\mathrm{N}-\mathrm{H} \\
\text { O.O.P }\end{array}$ & $\begin{array}{l}\text { Others } \\
\mathrm{N}=\mathrm{O}\end{array}$ \\
\hline I & $\begin{array}{l}2,507 \\
3,400\end{array}$ & 3,311 & 1,668 & $\begin{array}{l}1,556 \\
1,610\end{array}$ & 1,170 & 2798 & 665 & 1,490 & 806 & - \\
\hline II & - & - & 1,672 & 1,589 & 1,180 & 2800 & 692 & 1,490 & 842 & - \\
\hline III & - & 3,282 & $\begin{array}{l}1,679 \\
1,614\end{array}$ & 1,571 & 1,149 & 2922 & 646 & 1,502 & 788 & 1,342 \\
\hline IV & - & 3,344 & $\begin{array}{l}1,710 \\
1,652\end{array}$ & 1,523 & 1,112 & 2790 & 640 & 1,454 & 804 & 1,502 \\
\hline V & - & 3,398 & 1,735 & 1,569 & 1,132 & 2781 & 710 & 1,569 & 777 & - \\
\hline L1 & $\begin{array}{l}2,500 \\
3,400\end{array}$ & 3,309 & 1,697 & $\begin{array}{l}1,562 \\
1,608\end{array}$ & 1,172 & - & 607 & 1,498 & 812 & - \\
\hline L2 & $\begin{array}{l}2,341 \\
3,350\end{array}$ & 3,108 & 1,672 & 1,593 & 1,182 & - & 611 & 1,492 & 844 & - \\
\hline L3 & $\begin{array}{l}2,611 \\
3,367\end{array}$ & 3,182 & 1,679 & 1,573 & 1,151 & - & 648 & 1,500 & 796 & 1,340 \\
\hline L4 & $\begin{array}{l}2,374 \\
3,442\end{array}$ & 3,560 & $\begin{array}{l}1,695 \\
1,595\end{array}$ & 1,525 & 1,118 & - & 640 & 1,454 & 804 & - \\
\hline L5 & $\begin{array}{l}2,542 \\
3,450\end{array}$ & 3,210 & 1,740 & $\begin{array}{l}1,506 \\
1,612\end{array}$ & 1,130 & - & 702 & 1,506 & 746 & - \\
\hline
\end{tabular}

Fig. 1 Chemical structure of the new ligands; (L1) $N$ Glycylacetyl $p$-aminobenzoic acid, (L2) $N$-Glycylacetyl diphenylamine, (L3)

$N$-Glycylacetyl 4-chloro-2nitroaniline, (L4)

$\mathrm{N}$-Glycylacetyl 2-pyrimidine, and (L5) Bis(N-Glycylacetyl) phenylene diamine<smiles>O=C(O)CNCC(=O)Nc1ccc(C(=O)O)cc1</smiles>

(L1)<smiles>O=C(O)CNCC(=O)N(c1ccccc1)c1ccccc1</smiles>

(L2)<smiles>O=C(O)CNCC(=O)Nc1ccc(Cl)cc1[N+](=O)[O-]</smiles>

(L3)<smiles>O=C(O)CNCC(=O)Nc1ncccn1</smiles>

(L4)<smiles>O=C(O)CNCC(=O)NCC(=O)Nc1ccccc1NC(=O)O</smiles>

(L5)
Fig. 2 The UV-visible spectrum of $p$-amino benzoic acid (dashed line), $N$-formyl $p$ amino benzoic acid (dot-dashed line), and $N$-Glycylacetyl $p$ aminobenzoic acid (continuous line)

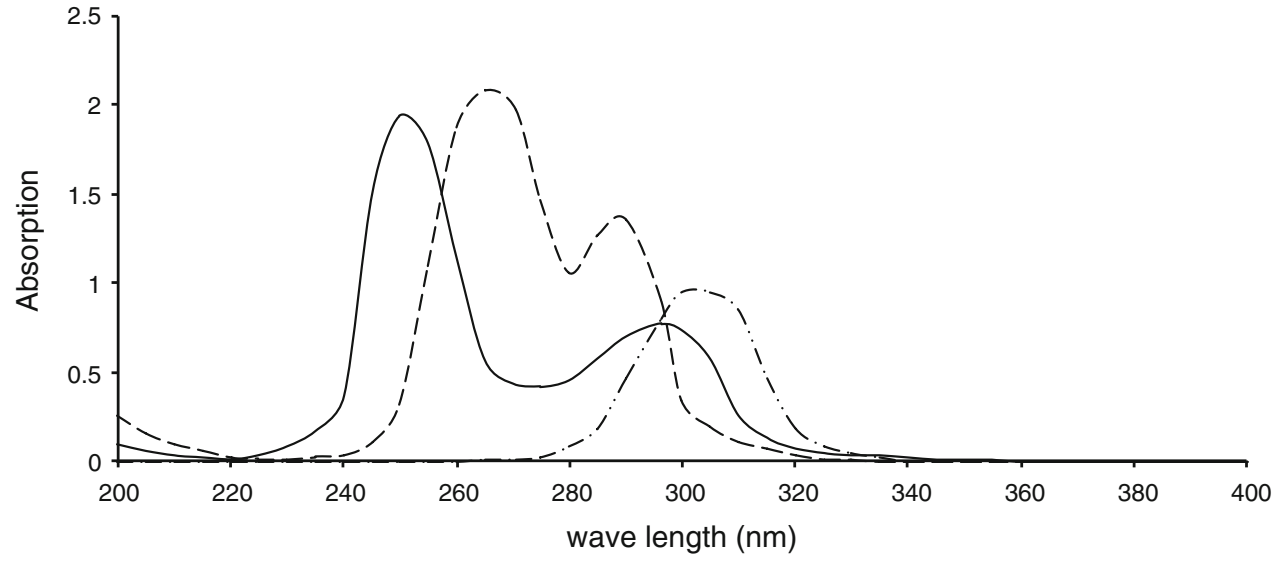


Fig. 3 The UV-visible spectrum of diphenyl amine (dashed line), $\mathrm{N}$-formyl diphenyl amine (dot-dashed line), and $N$-Glycylacetyl diphenylamine (continuous line)

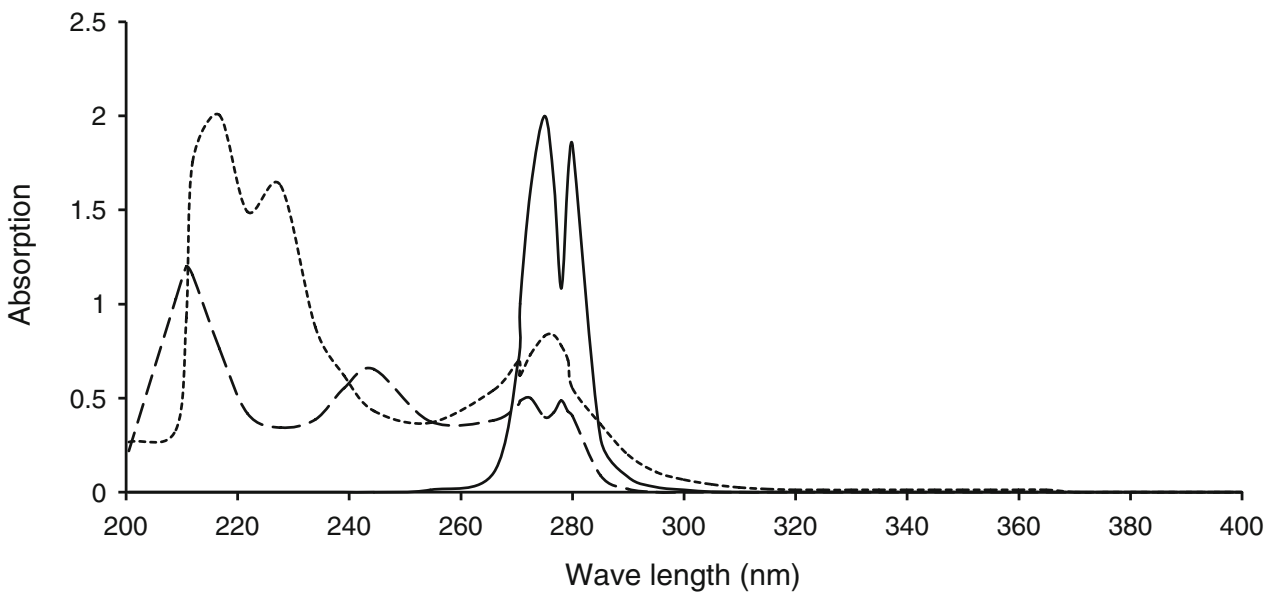

Fig. 4 The UV-visible spectrum of phenylene diamine (dashed line), $N, N^{\prime}$-diformyl phenylene diamine (dot-dashed line), and Bis-

$N, N^{\prime}$ (Glycylacetyl) phenylene diamine (continuous line)

Wave length $(\mathrm{nm})$
Fig. 5 Chromatography separation profile of the labeled ligands on a Sephadex G-25 column of ${ }^{99 \mathrm{~m}} \mathrm{Tc}$ pertechnetate labeling with (L1) $\mathrm{N}$ -

Glycylacetyl p-aminobenzoic acid, (L2) with $N$-Glycylacetyl diphenylamine,(L3) $\mathrm{N}$ -

Glycylacetyl 4-chloro-2-

nitroaniline, (L4) with $N$ -

Glycylacetyl 2-pyrimidine, and (L5) with $B i s(N$-Glycylacetyl) phenylene diamine
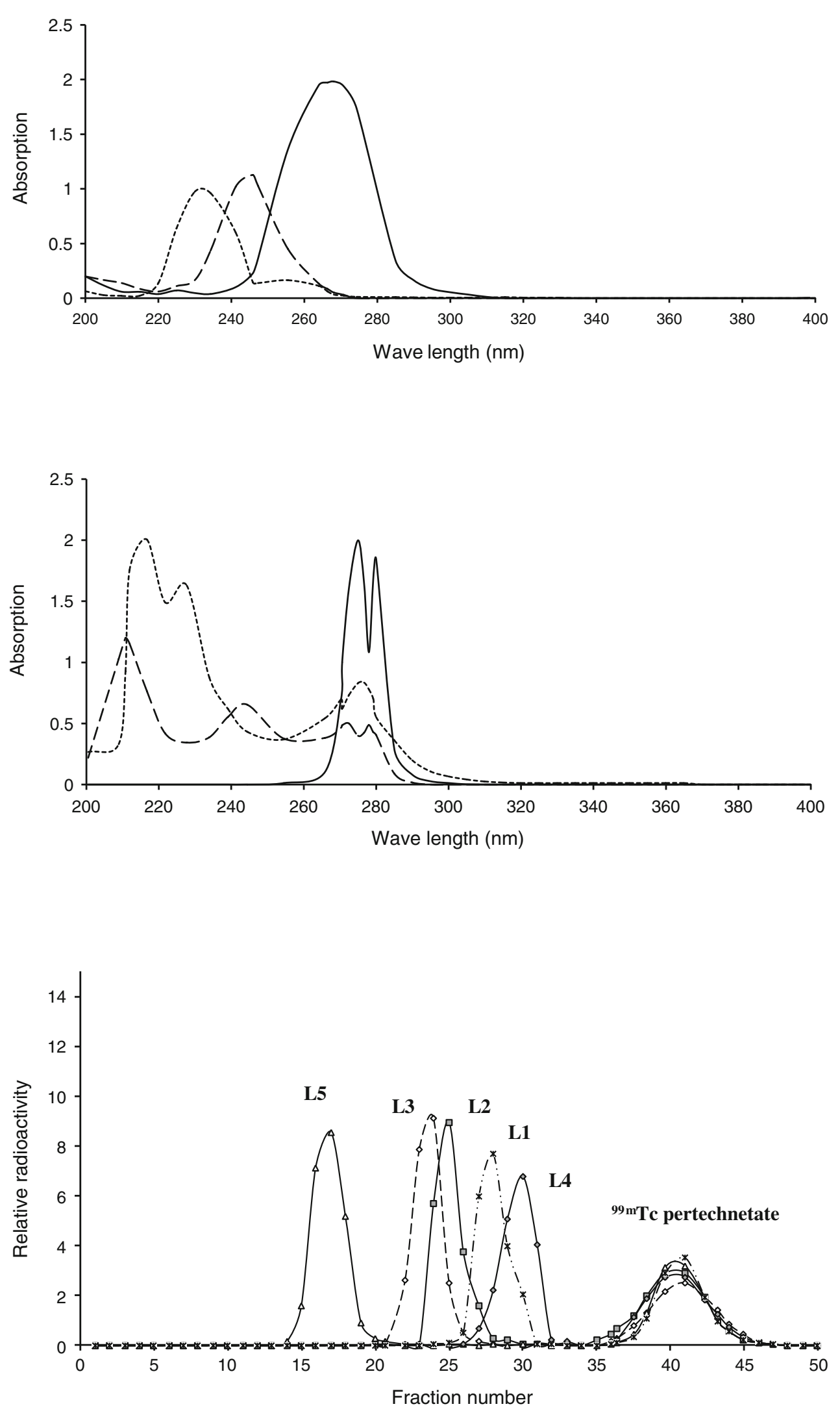
length upon substitution with the formyl group, and with methyl glycine after Mannich reaction. Generally, this shift is accompanied with increase in the value of $\lambda_{\max }$ of the products due to the hyperconjugation of the amine proton with benzene ring (Figs. 2, 3, 4). This new method will offer reliable procedure to design ligands of the following general structure.<smiles>[R]C(NCC(=O)Nc1ccc(NC(=O)CNC([R])C(=O)O)cc1)C(=O)O</smiles>

This structure will contain a lipophilic part of aromatic nucleus, and the hydrophilic part which can be any other amino acids. Rhenium complexes of these complexes were prepared by ligand substitution with the rhenium complex, oxotrichloro(triphenyl phosphine)rhenium(V) $\left[\mathrm{ReOCl}_{3^{-}}\right.$ $\left(\mathrm{PPh}_{3}\right)_{2}$ ] with 1:1 mol ratio of the metal:ligand. Chromatography profile of the labeled ligands on a Sephadex G-25 column shows that high percentage of the radioactivity was recovered in the void volume associated with the ligand fraction (Fig. 5). It gives good indication about the efficiency of labeling these ligands with $\mathrm{Na}^{99 \mathrm{~m}} \mathrm{TcO} 4$. Future work will be directed towards the direct application of these ligands in radiopharmaceutical imaging.

Open Access This article is distributed under the terms of the Creative Commons Attribution License which permits any use, distribution, and reproduction in any medium, provided the original author(s) and the source are credited.

\section{References}

1. Hom RK, Katzenellenbogen JA (1997) Nucl Med Biol 24:483
2. Jurisson SS, Lydon JD (1999) Potential Technetium Small Molecule Radiopharmaceuticals. Chem Rev 99:2205

3. Banerjee S, Pillai MRA, Ramamoorthy N (2001) Evolution of Tc-99m in diagnostic radiopharmaceuticals. Semin Nucl Med $31: 260-277$

4. Ryan J, Cooper M, Loberg M, Harvey E, Sikorski S (1977) Technetium-99m-labeled N-(2,6-dimethylphenylcarbamoylmethyl) imino-diacetic acid (Tc-99m HIDA): a new radiopharmaceutical for hepatobiliary imaging studies. J Nucl Med 18(10):997-1004

5. Hernandez M, Rosenthall L (1980) A cross-over study comparing the kinetics of Tc-99m-labeled isopropyl and $p$-butyl IDA analogs in patients. Clin Nucl Med 5:159-165

6. Karube $\mathrm{Y}$ et al (1999) Technetium-99m complex of $N$-(2-pyridylmethyl)-iminodiacetic acid as a new renal radiopharmaceutical. Ann Nucl Med 13(2):127

7. Martín D, Piera C, Mazzi U, Rossin R, Solans X, Font-Bardia M, and Suades J (2003) Rhenium and technetium-99m complexes with coenzyme M (MESNA). Dalton Trans, 15:3041-3045

8. Gal JL, Latapie L, Gressier M, Coulais Y, Dartiguenave M, Benoist E (2004) Design synthesis of a novel family of semi-rigid ligands: versatile compounds for the preparation of $99 \mathrm{mTc}$ radiopharmaceuticals. Org Biomol Chem 2(6):876-883

9. Wistow BW, Subramnian G, Van Heertum RL (1977) An evaluation of $99 \mathrm{mTc}$-labeled hepatobiliary agents. J Nucl Med 18:455-461

10. Qu T, Wang Y, Zhu Z, Rusckowski M, Hnatowich DJ (2001) Nucl Med Commun 22:203

11. Zhang C (2001) Foreign Med Sci Sect Radiat Med Nucl Med 25:97

12. Gil MC, Chandia VM, Errazu X (2001) Report, 99m-Tc labelled peptides for imaging of peripheral receptors. International Atomic Energy Agency, Vienna, p 29, 226 F

13. Jia F, Meng Z, Hu H, Wang H, Liu B (2001) Hejishu (Nucl Tech) 24:716

14. Oh SJ, Moon DH, Ha HJ, Park SW, Hong MK, Park SJ, Choi TH, Lim SM, Choi CW, Knapp FF, Lee HK (2001) Appl Radiat Isot 54:419

15. Okarvi SM, Adriaens P, Verbrruggen AM (2003) Synthesis and biological characteristics of technetium-99m triamide derivatives of mercaptoacetyle triglycine (MAG 3). J Label Compd Radiopharm 46:73-84

16. Hansen L, Taylor A Jr, Marzilli LG, Cini R (1992) Rhenium(V) oxo complexes relevant to technetium renal imaging agents derived from mercaptoacetylglycylglycyl aminobenzoic acid isomers. Structural and molecular mechanics studies. Inorg Chem 31:13

17. Van Bommel KJC, Verboom W, Hulst R, Kooijman H, Spek AL, Reinhoudt DN (2000) Calix[4]arene rhenium(V) complexes as potential radiopharmaceuticals. Inorg Chem 39:4099-4106

18. Chatt J, Rowe GA (1962) Complex compounds of tertiary phosphines and a tertiary arsine with rhenium (V), rhenium (III), and rhenium (II). J Chem Soc 4019-4033 